INTENSIVE JOURNAL

http://ojs.uniska-bjm.ac.id/index.php/EJB

E-ISSN 2620-4746

October 2021, Vol 4 No.2

\title{
The Relationship between Iraqi EFL Preparatory School Teacher` Teaching Anxiety and the Mastery of Daily Lesson Plan
}

\author{
Khansa H. AL- Bahadli \\ Imam AL-Kadhum (A.S.) College \\ Khansa_hassan@yahoo.com \\ Rasim T.Jehjooh \\ Imam AL-Kadhum (A.S.) College \\ rasimtayah@alkadhum-col.edu.iq
}

\begin{abstract}
Good teaching is the most basic important thing has teachers try to do in their classes and it is also in it the most frequently used language skills in communication activities. It plays an important role in the language learning process and facilitates the use of language skills. In this study the researchers tackled teaching anxiety that refers to the psychological response of a person to teaching task, which is determined by effect of feelings, believes and behaviors. And the relationship between teaching anxiety and the mastery of the daily lesson plan, which teaching means a system that enables a teacher to express himself/herself effectively with his/her interlocutors of a target language. The study questions are: Do Iraqi EFL preparatory school teachers have teaching anxiety? Do Iraqi EFL preparatory school teachers have mastery daily lesson plan? And is there any relationship between teaching anxiety and mastery daily lesson plan? Accordingly, the current study aims at finding out: Iraqi EFL preparatory school teachers' teaching Anxiety level, Iraqi EFL preparatory school teachers' mastery daily lesson plan level, and the relationship between Iraqi EFL preparatory School teachers teaching anxiety and the mastery of the daily lesson plan. The sample of the present study consists of (30) male and female teachers from Iraqi EFL preparatory school teachers chosen randomly from Baghdad city.

To achieve the aims of the present study, two instruments have been applied by the researchers, English Foreign language teaching anxiety scale and a English Foreign language lesson plan scale is constructed by the researchers themselves. After ensuring the validity and reliability of the instruments, the instruments have been applied and the data have been collected. Then a number of statistical tools have been used to analyze the obtained data.
\end{abstract}

Keywords: Teaching anxiety, EFL Lesson Plan. 
The Relationship between Iraqi EFL Preparatory School Teacher` Teaching Anxiety and the Mastery of Daily Lesson Plan

\section{INTRODUCTION}

Feeling anxious from time to time is normal. Also, moderate degree of anxiety is sometimes useful, as it helps the individual to react appropriately to the real danger, and helps motivate him to excel in his professional or family environment of the disease, and in patients who are characterized by a high degree of insight into their condition. When anxiety takes over and overpowers individuals, their lives become a series of inconveniences; It affects their performance, production, creativity and innovation, especially in high degrees of it, as it turns into neurotic anxiety. However, at a normal, moderate level, it is on the contrary; Anxiety becomes a positive and motivator for progress and problem solving.

\section{LITERATURE REVIEW}

Mashikhi (2009) says, "Anxiety is like radiation, beneficial if controlled and directed, but extremely harmful if left unchecked." Ibrahim (2016) states, "No individual lives without anxiety. While a small amount of anxiety is necessary for growth, a great deal of it is a hindrance."

Faraj (1990) indicates that there is a strong correlation between the negative aspects of psychological anxiety and the high degree, as well as the low degree of anxiety. Chronic high anxiety is what we call neurotic anxiety; It is the one whose intensity exceeds the individual's ability to bear, which leads him to take unrealistic and illogical ways, in short, neurotic ways with which he lacks his ability to deal with all situations in proportion to their performance. It is this type of anxiety that hinders human performance and disrupts his physical, mental, psychological, social, educational and professional capabilities. Also, when anxiety levels are low, the individual may become indifferent to the problems that are going on around him and indifferent to taking care of them.

Al-Masry (2010) stresses that anxiety has positive aspects as well as negative ones. This is in cases of moderate intensity anxiety, as this degree of anxiety is associated with the most consistent performance, unlike high neurotic anxiety or low anxiety. Normal anxiety is necessary for emotionally and mentally mature individuals, as it helps us deal with the problems that confront us in daily life situations with good efficiency. him to work and learn.

Al-Masry (2010) identifies three levels of anxiety as follows:

1. Low levels: A state of general alertness occurs for the individual, his alertness increases, his sensitivity to external events increases, his ability to resist danger increases, and the individual is in a state of motivation to confront the sources of danger in the environment in which he lives. Therefore, anxiety at this level is an indication of an impending danger.

2. Intermediate levels: the individual becomes less able to control; where behavior loses its flexibility and spontaneity, and inertia generally takes over the individual's actions in life situations, and his response and habit are those initial habits that are the most familiar. 
The Relationship between Iraqi EFL Preparatory School Teacher` Teaching Anxiety and the Mastery of Daily Lesson Plan

3. Higher levels: there is a decay and breakdown of the behavioral organization of the individual, and there is a regression to more primitive methods. Synergy and complementarity are greatly reduced in this case.

4. Accordingly, anxiety is a basic emotion in the individual that motivates him to work, innovate and think about finding solutions to problems that may require solutions from him, even in the normal circumstances he is going through, at moderate levels of it. However, if anxiety is not usually felt by the individual or exceeds the reasonable limit, it becomes disabling in both cases.

According to Albakri and Hussin (2014) the daily study plan is a process of preconception of the educational situation to achieve the goals, and the basis of this process is to define the goals, choose the methods of achieving them, and evaluate the extent to which they are achieved in a known period of time and for a specific level of students Gronlund and Brookhart, S.M. (2009). Al-Obaydi, et al. (2021) studied the socio-professional context of schools and this context can affect the behavior of teachers and student-teachers so the need to write action research or a lesson plan. The daily study plan is that level of short-term planning that the teacher sets to improve his performance for one lesson or a group of lessons that are a unit of study between them. Some teachers feel that planning is a functional duty without them being convinced of the importance of planning in their work, and therefore it is difficult for them to succeed in their work, and a number of questions are asked:

Is it conceivable that a qualified specialist teacher needs planning?

-Is the teacher unable to give a lesson in his field of specialization without prior planning?

Importance of the daily study plan:

Some teachers feel that planning is a functional duty without them being convinced of the importance of planning in their work, and therefore it is difficult for them to succeed in their work, and a number of questions are asked:

-Is it conceivable that a qualified specialist teacher needs planning?

-Is the teacher unable to give a lesson in his field of specialization without prior planning?

Does the teacher need a special note in which he writes down his preconceived notion of what he will do in the educational situation while he masters the material he is teaching by heart?

But we can answer these questions with the following questions: -

1. Did the teacher go through a situation in which he stood in front of his students in embarrassing situations after he finished the lesson in the first quarter of the class? And how did he act after that?

2. Did the teacher stand in front of a grim sentence or a vague word in one of the lessons, and his sweat was pouring out while the students looked at him while they were waiting for him to clarify the sentence or word?

3. Does the teacher diversify his methods and activities so as to motivate students to learn with longing and interest? (Albakri and Hussin, Kh,2014)

According to Anderson et al, (2001) lesson plan can: 
The Relationship between Iraqi EFL Preparatory School Teacher` Teaching Anxiety and the Mastery of Daily Lesson Plan

1. Motivates students to learn and longs for it

2. Protects them from the damages of confused education, misunderstanding and turmoil.

The teacher helps to clarify his vision of what he wants to achieve with the students, so he prepares the means and tools he needs, so that he feels confident in himself and the confidence of his students in him. Planning facilitates the learning process, whether in relation to the role of the teacher or the learner Harmer, J. (2007), makes the teacher aware of the objectives of the curricula that he plans to teach. It forces the teacher to analyze the content of the subjects he is studying. The teacher helps in employing effort and time and being convinced of them (Gronlund and Brookhart (2009). What is really important whether in writing good lesson planning or avoiding teachers' anxiety is to pay attention to the humanistic learning elements in the classroom that supposed to bring suitable learning environment or students (AlObaydi, 2021).

\section{RESEARCH DESIGN}

A correlational methodology has been applied in the present study. It is a kind of descriptive research that contains gathering data to prove if, and to what degree, a relationship between two or more quantifiable variables could occur (Gay et al, 2012, p.204).

McCombes (2019, p.12) said that the correlational research design aims to determine if there are any:

1. Positive correlation: both variables change in the same direction.

2. Negative correlation: the variables change in opposite directions.

3. Zero correlation: there is no relationship between the variables.

The researchers proposed to classify the two variables (Teaching anxiety and the effect the Lesson Plan) to find the sort of the relationship and if a change in one makes some change in the other or not.

\section{FINDINGS}

In order to achieve the first aim which is finding out the level of Iraqi EFL preparatory school teachers' teaching anxiety, Foreign Language teaching Anxiety Scale consisting of (20) items has been applied on the research sample consisting of (30) male and female teachers. The result indicates that the arithmetic mean score is (4.29) and the standard deviation is (1.11). In order to find out the significance of the difference between the arithmetic mean and the theoretical one, $\mathrm{t}$-test for one independent sample is used. It is found out that there is a statistically significant difference at (0.05) level of significance. See table (1) 
The Relationship between Iraqi EFL Preparatory School Teacher` Teaching Anxiety and the Mastery of Daily Lesson Plan

Table Teaching Anxiety

\begin{tabular}{|c|c|c|c|c|c|c|}
\hline & Questions & 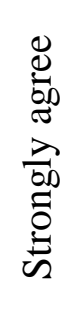 & 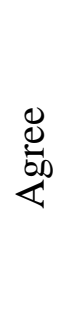 & 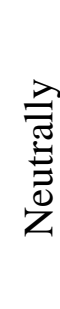 & 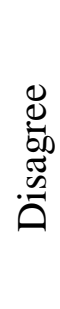 & 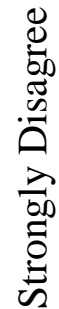 \\
\hline 1 & $\begin{array}{l}\text { I am anxious about how to give each students the attention to } \\
\text { my lessen. }\end{array}$ & 17 & 4 & 3 & 3 & 3 \\
\hline 2 & $\begin{array}{l}\text { I am anxious about setting work at the right level for my } \\
\text { students. }\end{array}$ & 14 & 5 & 6 & 2 & 3 \\
\hline 3 & I am anxious about class control. & 13 & 7 & 4 & 4 & 2 \\
\hline 4 & I am anxious about class control. & 14 & 8 & 4 & 3 & 1 \\
\hline 5 & I am anxious about whether or not my plans will adequate. & 16 & 4 & 5 & 4 & 1 \\
\hline 6 & I am anxious about whether or not my plans will adequate. & 26 & 4 & 0 & 0 & 0 \\
\hline 7 & $\begin{array}{l}\text { I am anxious about possible problems in the class with } \\
\text { individual disruptive student. }\end{array}$ & 14 & 8 & 4 & 3 & 1 \\
\hline 8 & I am anxious about completing the required lesson plan. & 26 & 2 & 1 & 1 & 0 \\
\hline 9 & I am anxious about the learning objective of my lesson plane. & 25 & 4 & 1 & 0 & 0 \\
\hline 10 & $\begin{array}{l}\text { I am anxious about evaluating of lesson plan whether or not } \\
\text { suitable. }\end{array}$ & 23 & 4 & 1 & 2 & 0 \\
\hline 11 & $\begin{array}{l}\text { I am anxious about the methods and approaches that are } \\
\text { followed in my lesson. }\end{array}$ & 22 & 4 & 1 & 2 & 1 \\
\hline 12 & I am anxious about getting on with the school staff. & 20 & 4 & 3 & 3 & 0 \\
\hline 13 & I am anxious about what my supervisor will expect. & 22 & 3 & 2 & 2 & 1 \\
\hline 14 & I am anxious about incidents of misbehavior in my class. & 13 & 7 & 5 & 3 & 2 \\
\hline 15 & I am anxious about misunderstanding of my lesson. & 15 & 8 & 4 & 2 & 1 \\
\hline 16 & I am anxious about unsuccessful lessons. & 20 & 5 & 3 & 2 & 0 \\
\hline 17 & $\begin{array}{l}\text { I am anxious about whether or not I will cover the material a } \\
\text { adequately. }\end{array}$ & 19 & 5 & 3 & 2 & 1 \\
\hline 18 & I am anxious about selecting a suitable lesson content. & 15 & 8 & 3 & 3 & 1 \\
\hline 19 & $\begin{array}{l}\text { I am anxious about whether or not my performance will be } \\
\text { satisfactory. }\end{array}$ & 19 & 4 & 3 & 2 & 2 \\
\hline 20 & I am anxious about selecting suitable teaching aids. & 25 & 2 & 3 & 2 & 0 \\
\hline
\end{tabular}


The Relationship between Iraqi EFL Preparatory School Teacher` Teaching Anxiety and the Mastery of Daily Lesson Plan

Table

Teaching Anxiety

\begin{tabular}{|c|c|c|c|c|c|c|c|c|c|}
\hline N. & 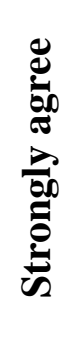 & 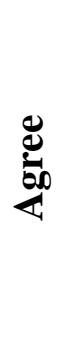 & 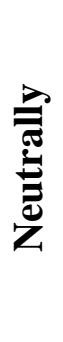 & 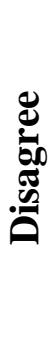 & 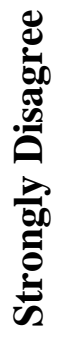 & $\sum_{\dot{n}}^{\infty}$ & $\stackrel{P}{\circ}$ & 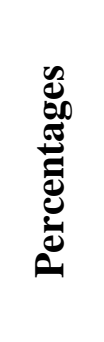 & Rank \\
\hline 1 & 17 & 4 & 3 & 3 & 3 & 3.97 & 1.4 & 79.4 & Agree \\
\hline 2 & 14 & 5 & 6 & 2 & 3 & 3.83 & 1.34 & 76.6 & Agree \\
\hline 3 & 13 & 7 & 4 & 4 & 2 & 3.83 & 1.29 & 76.6 & Agree \\
\hline 4 & 14 & 8 & 4 & 3 & 1 & 4.03 & 1.14 & 80.6 & Agree \\
\hline 5 & 16 & 4 & 5 & 4 & 1 & 4 & 1.24 & 80 & Agree \\
\hline 6 & 26 & 4 & 0 & 0 & 0 & 4.87 & 0.34 & 97.4 & Strongly Agree \\
\hline 7 & 14 & 8 & 4 & 3 & 1 & 4.03 & 1.14 & 80.6 & Agree \\
\hline 8 & 26 & 2 & 1 & 1 & 0 & 4.77 & 0.67 & 95.4 & Strongly Agree \\
\hline 9 & 25 & 4 & 1 & 0 & 0 & 4.8 & 0.48 & 96 & Strongly Agree \\
\hline 10 & 23 & 4 & 1 & 2 & 0 & 4.6 & 0.84 & 92 & Strongly Agree \\
\hline 11 & 22 & 4 & 1 & 2 & 1 & 4.47 & 1.06 & 89.4 & Strongly Agree \\
\hline 12 & 20 & 4 & 3 & 3 & 0 & 4.37 & 1.02 & 87.4 & Strongly Agree \\
\hline 13 & 22 & 3 & 2 & 2 & 1 & 4.43 & 1.09 & 88.6 & Strongly Agree \\
\hline 14 & 13 & 7 & 5 & 3 & 2 & 3.87 & 1.26 & 77.4 & Agree \\
\hline 15 & 15 & 8 & 4 & 2 & 1 & 4.13 & 1.09 & 82.6 & Agree \\
\hline 16 & 20 & 5 & 3 & 2 & 0 & 4.43 & 0.92 & 88.6 & Strongly Agree \\
\hline 17 & 19 & 5 & 3 & 2 & 1 & 4.3 & 1.1 & 86 & Strongly Agree \\
\hline 18 & 15 & 8 & 3 & 3 & 1 & 4.1 & 1.14 & 82 & Agree \\
\hline 19 & 19 & 4 & 3 & 2 & 2 & 4.2 & 1.25 & 84 & Strongly Agree \\
\hline
\end{tabular}


The Relationship between Iraqi EFL Preparatory School Teacher` Teaching Anxiety and the Mastery of Daily Lesson Plan

\begin{tabular}{|l|l|l|l|l|l|l|l|l|l|}
20 & 25 & 2 & 3 & 0 & 0 & 4.73 & 0.63 & 94.6 & Strongly Agree \\
\hline
\end{tabular}

\begin{tabular}{|c|c|c|c|c|}
\hline Weighted mean & M.S & S.D & Percentages & Rank \\
\cline { 2 - 5 } & 4.29 & 1.11 & 85.8 & Strongly Agree \\
\hline
\end{tabular}

\section{Result Related to the Second Aim}

In order to achieve the second aim which is finding out the level of Iraqi EFL preparatory school teachers' mastery daily lesson plan?

, Foreign Language teaching mastery daily lesson plan Scale consisting of (20) items has been applied on the research sample consisting of (30) male and female teachers. The result indicates that the arithmetic mean score is (3.94) and the standard deviation is (1.29). In order to find out the significance of the difference between the arithmetic mean and the theoretical one, t-test for one independent sample is used. It is found out that there is a statistical significant difference at $(0.05)$ level of significance. See table (2)

Table (2) Lesson planning questionnaire

\begin{tabular}{|c|c|c|c|c|c|c|}
\hline N. & Questions & 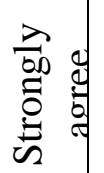 & 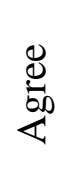 & 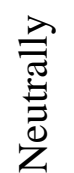 & 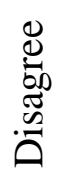 & 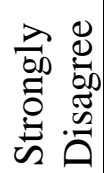 \\
\hline 1 & $\begin{array}{l}\text { It is important to estimate how long each part of the lesson } \\
\text { will take. }\end{array}$ & 15 & 6 & 4 & 3 & 2 \\
\hline 2 & $\begin{array}{l}\text { Lesson plan should include a balance of interaction during the } \\
\text { class. }\end{array}$ & 35 & 11 & 3 & 1 & 0 \\
\hline 3 & Not always I need to prepare my lesson plan. & 3 & 3 & 9 & 7 & 8 \\
\hline 4 & $\begin{array}{l}\text { I need to leave time at the end of the lesson to gather } \\
\text { feedback. }\end{array}$ & 15 & 8 & 4 & 2 & 1 \\
\hline 5 & $\begin{array}{l}\text { I don't see any importance to the daily lesson plan in my } \\
\text { teaching. }\end{array}$ & 0 & 5 & 6 & 8 & 11 \\
\hline 6 & Lesson plan is time consuming. & 5 & 4 & 6 & 6 & 9 \\
\hline 7 & $\begin{array}{l}\text { Lesson plan helps me to think through what learners will } \\
\text { achieve in the lesson. }\end{array}$ & 21 & 5 & 2 & 2 & 0 \\
\hline 8 & $\begin{array}{l}\text { Lesson plan provides a framework for organizing ideas, } \\
\text { methodology, materials etc. }\end{array}$ & 19 & 5 & 3 & 2 & 1 \\
\hline 9 & $\begin{array}{l}\text { Lesson plan helps me to know where they are going and how } \\
\text { they are going to get there. }\end{array}$ & 15 & 7 & 5 & 3 & 0 \\
\hline 10 & It helps me to make the lesson coherent. & 18 & 6 & 4 & 1 & 1 \\
\hline 11 & it Avoids over-domination of course books. & 14 & 6 & 6 & 3 & 1 \\
\hline
\end{tabular}


The Relationship between Iraqi EFL Preparatory School Teacher` Teaching Anxiety and the Mastery of Daily Lesson Plan

\begin{tabular}{|c|c|c|c|c|c|c|}
\hline 12 & $\begin{array}{l}\text { It demonstrates to learners that teacher knows what s/he is } \\
\text { doing. }\end{array}$ & 14 & 9 & 5 & 2 & 0 \\
\hline 13 & it prepares boosts teacher confidence. & 18 & 4 & 7 & 1 & 0 \\
\hline 14 & $\begin{array}{l}\text { It helps to identify any problems or difficulties which may } \\
\text { arise during the lesson. }\end{array}$ & 18 & 6 & 3 & 2 & 1 \\
\hline 15 & It helps teachers to adapt to different classes. & 14 & 5 & 7 & 3 & 1 \\
\hline 16 & It helps teachers to reflect on after the lesson. & 16 & 4 & 5 & 4 & 1 \\
\hline 17 & $\begin{array}{l}\text { It helps to identify the kinds of activities and materials to } \\
\text { include to achieve aims. }\end{array}$ & 17 & 4 & 3 & 5 & 1 \\
\hline 18 & A plan can link the lesson explicitly to syllabus objectives. & 22 & 4 & 3 & 1 & 0 \\
\hline 19 & It saves time and helps teachers feel more prepared. & 21 & 3 & 3 & 3 & 0 \\
\hline 20 & Only the objective of the daily lesson plan is important. & 13 & 4 & 8 & 3 & 2 \\
\hline
\end{tabular}

\begin{tabular}{|c|c|c|c|c|c|c|c|c|c|}
\hline N. & 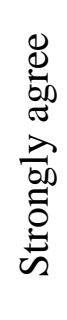 & 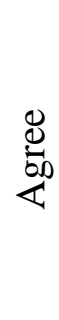 & 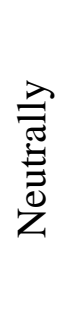 & 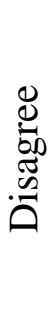 & 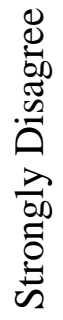 & $\sum_{\Sigma}^{\infty}$ & $\stackrel{\theta}{\ddot{n}}$ & 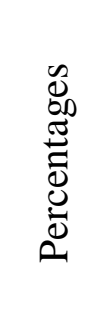 & Rank \\
\hline 1 & 15 & 6 & 4 & 3 & 2 & 3.97 & 1.28 & 79.4 & Agree \\
\hline 2 & 22 & 4 & 3 & 1 & 0 & 4.57 & 0.8 & 91.4 & Strongly Agree \\
\hline 3 & 3 & 3 & 9 & 7 & 8 & 2.53 & 1.26 & 50.6 & Disagree \\
\hline 4 & 15 & 8 & 4 & 2 & 1 & 4.13 & 1.09 & 82.6 & Agree \\
\hline 5 & 0 & 5 & 6 & 8 & 11 & 2.17 & 1.1 & 43.4 & Disagree \\
\hline 6 & 5 & 4 & 6 & 6 & 9 & 2.67 & 1.45 & 53.4 & Neutrally \\
\hline 7 & 21 & 5 & 2 & 2 & 0 & 4.5 & 0.89 & 90 & Strongly Agree \\
\hline 8 & 19 & 5 & 3 & 2 & 1 & 4.3 & 1.1 & 86 & Strongly Agree \\
\hline 9 & 15 & 7 & 5 & 3 & 0 & 4.13 & 1.02 & 82.6 & Agree \\
\hline 10 & 18 & 6 & 4 & 1 & 1 & 4.3 & 1.04 & 86 & Strongly Agree \\
\hline 11 & 14 & 6 & 6 & 3 & 1 & 3.97 & 1.17 & 79.4 & Agree \\
\hline 12 & 14 & 9 & 5 & 2 & 0 & 4.17 & 0.93 & 83.4 & Agree \\
\hline 13 & 18 & 4 & 7 & 1 & 0 & 4.3 & 0.94 & 86 & Strongly Agree \\
\hline 14 & 18 & 6 & 3 & 2 & 1 & 4.27 & 1.09 & 85.4 & Strongly Agree \\
\hline 15 & 14 & 5 & 7 & 3 & 1 & 3.93 & 1.18 & 78.6 & Agree \\
\hline 16 & 16 & 4 & 5 & 4 & 1 & 4 & 1.24 & 80 & Agree \\
\hline 17 & 17 & 4 & 3 & 5 & 1 & 4.03 & 1.28 & 80.6 & Agree \\
\hline 18 & 22 & 4 & 3 & 1 & 0 & 4.57 & 0.8 & 91.4 & Strongly Agree \\
\hline 19 & 21 & 3 & 4 & 2 & 0 & 4.43 & 0.96 & 88.6 & Strongly Agree \\
\hline 20 & 13 & 4 & 8 & 3 & 2 & 3.77 & 1.28 & 75.4 & Agree \\
\hline
\end{tabular}


The Relationship between Iraqi EFL Preparatory School Teacher` Teaching Anxiety and the Mastery of Daily Lesson Plan

\begin{tabular}{|c|c|c|c|c|}
\hline Weighted mean & M.S & S.D & Percentages & Rank \\
\cline { 2 - 5 } & 3.94 & 1.29 & 78.8 & Agree \\
\hline
\end{tabular}

\section{Result Related to the Third Aim}

The third aim is concerned with finding out the relationship between Iraqi EFL preparatory School teachers` teaching anxiety and the mastery of the lesson plan. To achieve this aim, the researchers took the answers of the research sample on the scale of teaching anxiety and their on the questionnaire of the mastery of the lesson plan, then used the Pearson correlation coefficient and the results show the value of the correlation coefficient between teaching anxiety and mastery of the lesson plan is found to be (0.317-), and to know the significance of the relationship, the researcher used the T-test, the calculated t-value (4.284), is found to be higher than the tabulated value (1.96) at (0.05) level of significance (163) degree of freedom, and this means that the relationship between teaching anxiety and mastery of the lesson plan is a statistically significant inverse relationship meaning that the higher the teachers' teaching anxiety comes with lower their mastery of the lesson plan.

\section{CONCLUSION}

In view of the study's results, the following Recommendations are stated The educational teacher moves away from randomness during the teaching process, which surrounds the tasks of the educational teacher, as the performance of the educational teacher turns into a set of organized, coordinated and interconnected steps, prepared in order to achieve a set of goals within the educational and educational process. It leads to clarity of vision for the educational teacher, as this contributes to accurately defining the students' previous experiences and the objectives of the current educational process, after which he is able to develop and prepare the best appropriate procedures for implementing and evaluating the teaching process.

It affects the growth of the educational teacher's experiences from a scientific point of view periodically and continuously, due to his passing through a group of different experiences, during the planning of lessons, as these experiences differ from time to time due to the change that takes place in the curricula that the educational teacher is based on. Teaching it to students, as well as the change in educational goals, the content of the curricula, and social problems and other matters and events are related to the teaching process. The study plan spares the educational teacher from many sudden situations, as this is often due to entering the world of the daily teaching process without a preconceived vision of sudden events in the world of teaching such as the use of technology in teaching and learning English (Dayu, \& Haura, 2016). 
The Relationship between Iraqi EFL Preparatory School Teacher` Teaching Anxiety and the Mastery of Daily Lesson Plan

\section{REFERENCES}

Al-Obaydi, L. H., Nashruddin, N., Rahman, F. F., \& Suherman, L. A. (2021). The Use of Action Research in EFL Socio-professional Context: Studentsteachers' Perceptions. ELS Journal on Interdisciplinary Studies in Humanities. 4(2). DOI: https://doi.org/10.34050/elsjish.v4i2.10876

Liqaa Habeb Al-Obaydi (2021): Humanistic learning elements in a blended learning environment: a study in an EFL teaching context, Interactive Learning Environments, DOI: https://doi.org/10.1080/10494820.2021.1919717

Albakri and Hussin, Kh(2014) Undergraduate Practicum Course. Dar Al kfeel, Kerbala:Iraq

Anderson, L. W. and David R. Krathwohl, D. R., et al (Eds..) (2001) A Taxonomy for Learning, Teaching, and Assessing: A Revision of Bloom's Taxonomy of Educational Objectives. Allyn and Bacon. Boston, MA (Pearson Education Group).

Dayu, A. T. \& Haura, R. (2016). Video Recording Mobile Phone Camera of Micro Teaching Subject in Teaching Skills of Students Teacher: The Case of Students Teacher Education in Islamic Kalimantan University MAB Banjarmasin. ICTTE. 1(1)

Ghaleb Mohammed Al-Mashikhi (2009): Future anxiety and its relationship between self-efficacy and the level of Ambition among a sample of Taif University students, a PhD thesis, Umm Al-Qura University, College of Education.

Faraj Abdel Qader (1990): A Dictionary of Psychology and Psychoanalysis, Beirut, Dar Al-Nahda Arabia .

Ibrahim, Taha Younes (2016): The effect of a web-based quest strategy on developing teaching skills and reducing Teaching anxiety among student teachers at the College of Education - Majmaah University (Saudi Arabia), research published in Educational Journal, Faculty of Education, Sohag University, Vol, 44 
The Relationship between Iraqi EFL Preparatory School Teacher` Teaching Anxiety and the Mastery of Daily Lesson Plan

Gay, L.R., Mills, G.E. \& Airasian, P.W. (2012). Educational Research:Competencies for Analysis and Application. 10th ed.

Gronlund ,N.E., and Brookhart,S.M.(2009).Gronlund's Writing Instructional Objectives.Upper Saddle River,NJ : Pearson/ Prentice-Hall.

Harmer, J. (2007).Planning lessons .In the Practice of English Language Teaching.( pp. 364-78). Harlow, Essex: Pearson Education.

Kumar, R. (2018). Research methodology: A step-by-step guide for beginners. Sage.

Nevin Al-Masry (2010): The anxiety of the future and its relationship to both the efficacy of the self and the level of ambition .The academic at Ainu from the students of Al-Azr University in Gaza, Master's thesis, Faculty of Education, University of Al-Azar, Gaza, and Mostif

McCombes,S.(2019).Correlationalresearch.https://www.scribbr.com/ methodology/correlational-research.

Mills, G. E., \& Gay, L. R. (2019). Educational research: Competencies for analysis and applications. Pearson. One Lake Street, Upper Saddle River, New Jersey 07458 . 